\title{
Evaluation of Reactivity and Inhibitions in Developing Municipal Solid Waste Landfill Bioreactors for Tropical Climatic Conditions
}

\author{
H.A.Y.R. Gunarathna, S.A. Karunarathne ${ }^{1}$, B.F.A. Basnayake ${ }^{2}$ \\ T. Sangeetha ${ }^{3}$ and L.W. Galagedara ${ }^{2}$ \\ Centre for Renewable Energy Sources (CRES) \\ Postgraduate Institute of Agriculture \\ University of Peradeniya \\ Peradeniya, Sri Lanka
}

\begin{abstract}
Landfill bioreactor concept is one of the novel technologies to satisfy the emergent power requirement of the world while minimizing the burden on the environment from municipal solid waste (MSW). However, performance evaluations of landfill bioreactors $(L B R)$ studies in terms of defining failure in tropics were few. Three stages of researches in series were carried out for overcoming the shortcomings.
\end{abstract}

In stage-1, a concrete lysimeter simulating a control landfill with diameter $1.3 \mathrm{~m}$ and height $3.32 \mathrm{~m}$ was constructed and filled with $2727.9 \mathrm{~kg}$ of MSW. Stage-2 LBR-1 was constructed with a lower height $1.8 \mathrm{~m}$ and loaded with $1149.6 \mathrm{~kg}$ of MSW to identify the leachate recirculation effects to accelerate biological activity. Stage-2 LBR-2 was constructed with similar dimensions in stage-1 control landfill and $2052.7 \mathrm{~kg}$ of MSW was applied to enhance gas production and identify onset of inhibitions and toxicity. Finally, stage-3 LBR "test cell" was constructed with an extent of $8.3 \times 5.3 \mathrm{~m}^{2}$ and $51,940 \mathrm{~kg}$ of MSW filed at a placement density of $756.3 \mathrm{~kg} / \mathrm{m}^{3}$. Bottom liner plus capping was constructed using clay -polyethyleneclay composite layer to minimize the toxicity and outfit the conditions.

Stage-1 control landfill study explains the effect of rainfall on leachate generation and biological degradation. Stage-2 LBR-1 explains effect of leachate re-circulation and inoculation of cow dung on biological processes. Nevertheless, in LBR-2 created inhibitions

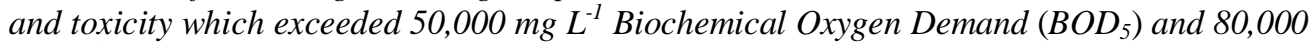
$m g L^{-1}$ Chemical Oxygen Demand (COD). Finally, the LBR 'test cell' liner removed nitrate nitrogen $30.1 \pm 1.9 \mathrm{mg} \mathrm{L}^{-1}$, ionic compounds in the system and achieved standard permeability while generating helpful renewable landfill gas.

\section{INTRODUCTION}

The rapid growth of the population and improvement of living standards have created notable pressure on the natural environment of the country. Disposal of Municipal Solid Waste (MSW) is a critical issue due to limitation of available lands in the most of the urban centers. Therefore, rehabilitation of existing open dumpsites and application of advanced

\footnotetext{
1 Department of Chemical and Biological Engineering, University of Maine, USA

2 Department of Agricultural Engineering, University of Peradeniya, Sri Lanka

3 Department of Agricultural Engineering, University of Jafna, Sri Lanka
} 
engineering techniques in future waste disposal facilities are the most realistic approaches to resolve this problem (Nagendran et al., 2006).

Selection of sites, construction, operation and monitoring of the modern landfills facilities are complex due to negative environmental impacts associated with MSW. Production of leachate and transport away from the landfill sites has lead to pollution of ground and surface water bodies (Loizidou and Kapetanios, 1993). At the same time landfill gas emissions can lead to adverse health effects and global warming. Furthermore, spread of animal and insect vectors diseases associated with MSW make open dumps unsustainable (Das et al., 2002). Therefore, in order to overcome the above environmental consequences and emergent power requirements all over the world, the trend is to convert open dumps to more energy recovering landfill bioreactors.

A landfill bioreactor is a sanitary engineered landfill that uses enhanced microbiological processes to transform and stabilize the readily and moderately decomposable organic waste constituents within 5 to 10 years. Most of the research conducted all over the world are to create wet conditions in landfills by leachate recirculation (Reinhart and Townsend, 1998) and external water or treated leachate addition (Sanphotia et al., 2006). Although, a higher rate of liquid application can enhance the biological degradation and gas production for energy recovery (Sponza and Agdag, 2003), during the past decades, research studies were few, lacking of performance evaluations in terms of defining failure, particularly in the tropics.

Therefore, the lack of technology of suitable bio film liners to minimize inhibitions and toxicity inside the reactors were the reasons for undertaking the task of developing landfill bioreactor (LBR) technology for tropical climatic conditions. This paper describes the research studies carried out as a series in reporting the shortcomings that took place in developing landfill bioreactors to minimize inhibitions and toxicity inside the reactor while maintaining continuous landfill gas production.

\section{MATERIALS AND METHODS}

A series of research studies were conducted in three stages. Stage-1 was lysimeter establishment as control landfill to identify landfill conditions. The stage-2 LBR-1 was constructed to identify the leachate recirculation impacts and to accelerate biological activity. Also, during stage-2, LBR-2 research was carried out to enhance gas production and identify onset of inhibitions and toxicity. Finally, in the stage-3, LBR "test cell" was established with low cost clay-polyethylene-clay liner to minimize the toxicity inside the reactor and outfit the conditions. During the third study, moisture was added continuously through leachate recirculation, precipitation to enhance, and continuous methane gas generation while facilitating rapid waste decomposition.

\section{Simulation of controlled landfill condition at stage-1}

During the stage-1, a concrete lysimeter simulating a control landfill was constructed with a diameter of $1.3 \mathrm{~m}$ and the height of $3.32 \mathrm{~m}$. It was $2.32 \mathrm{~m}$ below the ground level and the rest $(1.0 \mathrm{~m})$ was above the ground level. To facilitate the filtration of leachate and their movement, gravel was placed at the bottom of the control landfill while maintaining a slope towards the front side. Leachate collecting pipe was installed at the end of the slope. The technical details of the constructed control landfill are given in Fig. 1. 


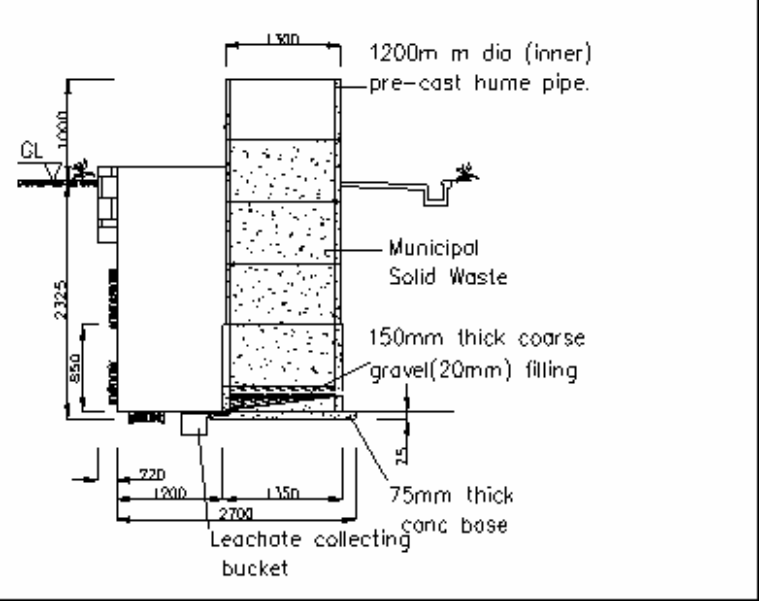

Fig. 1. Schematic view of controlled landfill established during stage-1

\section{Simulation bioreactor landfill condition at stage-2}

In stage-2, a LBR-1 was built using concrete rings with the diameter of $1.3 \mathrm{~m}$ and height of $1.8 \mathrm{~m}$ above ground. The LBR-1 was converted to landfill bioreactor by embedding perforated gas extraction pipe $(0.025 \mathrm{~m}$ diameter with a $0.30 \mathrm{~m}$ thick gravel pack) and leachate collection method similar to the previous control landfill at stage- 1 , but a leachate recirculated system was installed. Top of the LBR-1 was covered using HDPE cover to prevent rainfall incorporation into the system. Technical details of LBR are shown in Fig. 2.

\section{Construction of LBR-2 at stage-2}

During stage-2, another LBR-2 was constructed following the LBR-1 study by modifying the capping system. The top of the bioreactor was sealed by using a steel jacket and a water barrier. The gas collection pipe was connected to the steel jacket and a condenser made out of copper spiral tube was used to facilitate the condensation of moisture in landfill gas. Leachate collection and recirculate system were installed similar to the LBR-1 study. The Fig. 3 illustrates the schematic diagram of the anaerobic LBR-2. 


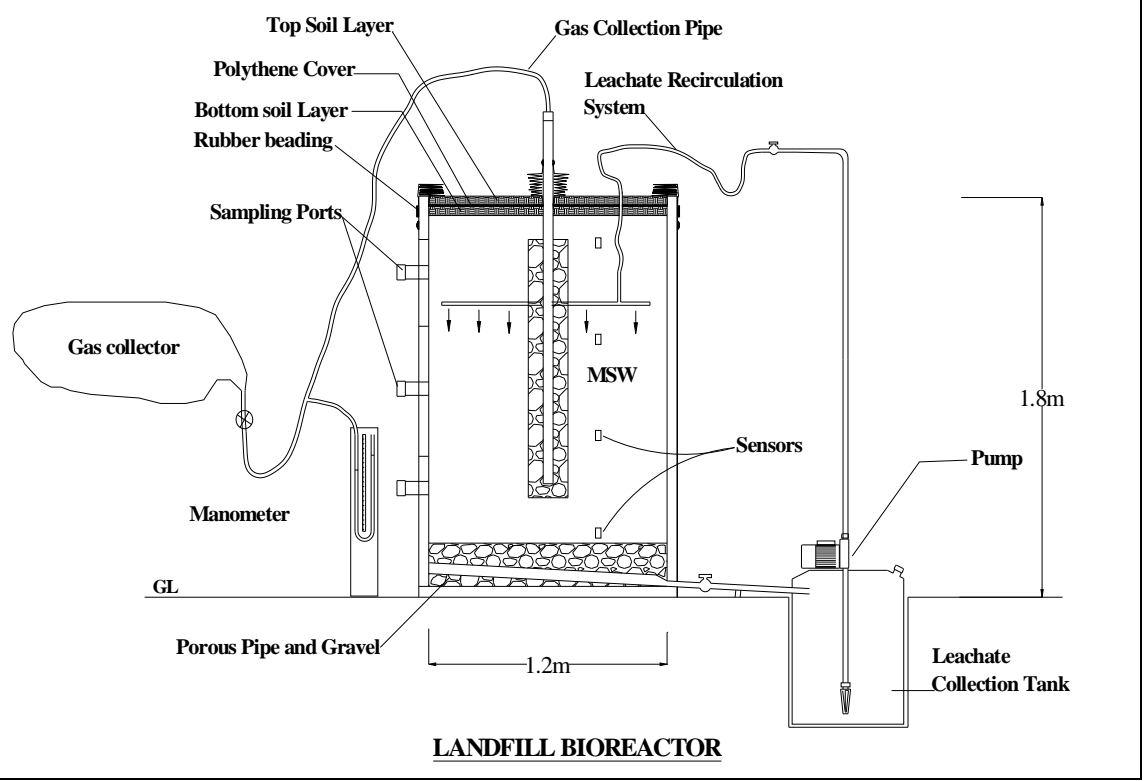

Fig. 2. Schematic view of bioreactor landfill established during stage-2

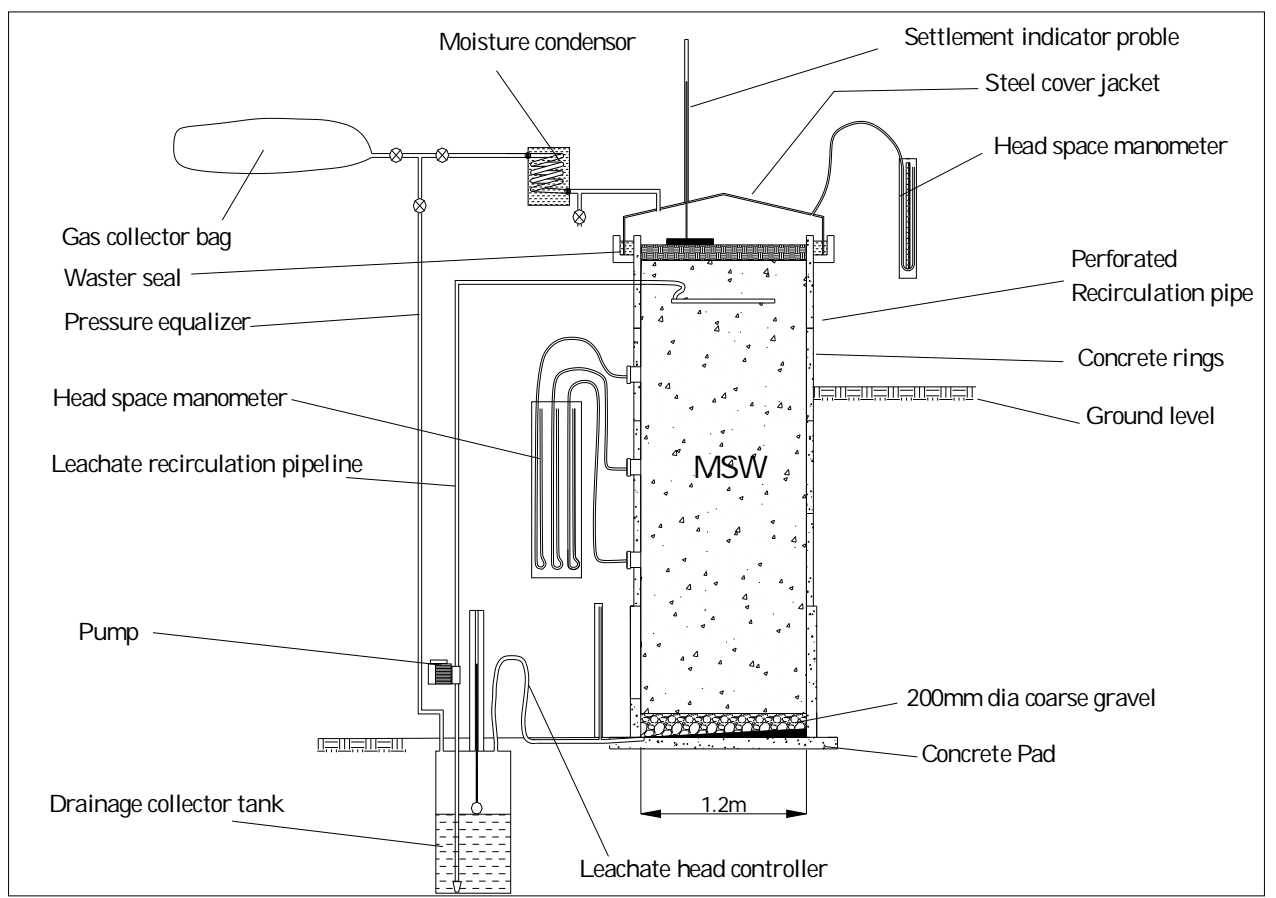

Fig. 3. Schematic diagram of the anaerobic landfill bioreactor (LBR-2) 


\section{Construction of LBR 'test cell' at stage-3}

After getting the relevant information from the above two stages, the stage-3 LBR 'test cell' was constructed over a period of three months in an extent of $8.3 \times 5.3 \mathrm{~m}^{2}$ with a total volume of $68.68 \mathrm{~m}^{3}$. Bottom liner and capping was constructed using clay-polyethylene-clay composite liners which consist of 0.05 m layers each (Gunarathna et al., 2007). The low density polythene of 1000 gauge was used to prevent deep percolation, enabling collection of it to determine the quality parameters of permeate.

The weights of each waste load were obtained and the composition was noted. A total 51.94 tonnes of MSW (37.48 tonnes dry basis) were filled with an average placement density of $756.3 \mathrm{~kg} \mathrm{~m}^{-3}$. Two gas extraction wells were constructed using $0.05 \mathrm{~m}$ perforated pipe inside the $0.3 \mathrm{~m}$ diameter gravel pack and leachate recirculation system was installed. After application of final clay-polyethylene-clay capping, turfing was done.

The leachate recirculation system was first operated manually and number of parameters such as leachate seeping rate, quantity of leachate recycled, rate of permeate through the composite liner and the leachate head in the reactor were measured. Then leachate recirculation system was improved and the system was automated to prevent excessive accumulation of leachate in the collection tanks. Gas was continuously extracted using diaphragm ventilator at a fixed rate of $4.2 \mathrm{~L}$ per min. A small torch was fabricated to combust the landfill Gas (LFG) completely. The conceptual design of landfill bioreactor test cell is shown in Fig. 4.

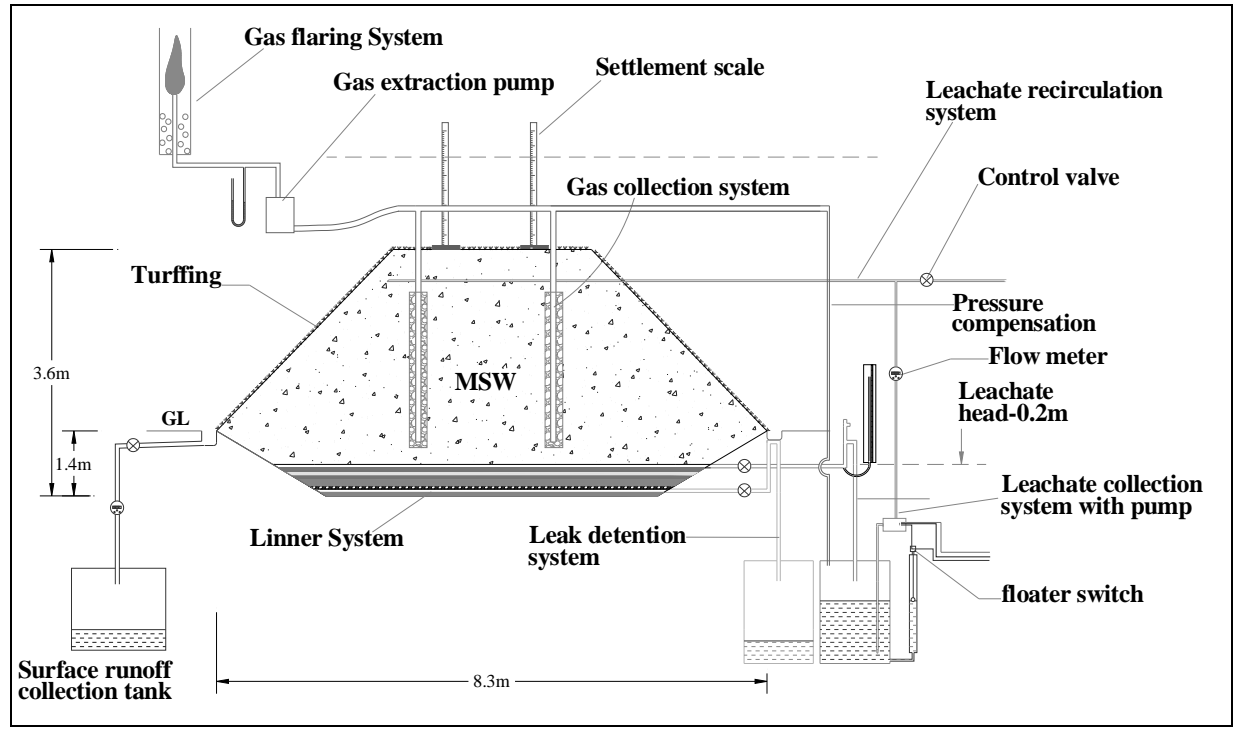

Fig. 4. Schematic view of bioreactor 'test cell' established during stage-3

\section{Amount of waste used for landfill and LBR's}

Table 1 shows the summary of MSW used for the above 4 researches respectively. In each and every research, MSW composition study was carried out before loading the waste. Table 2 gives the different parameters analyzed in the above four separate researches and Table 3 gives different conditions and status of the each reactor. 
Table 1. Different conditions applied for above studies.

\begin{tabular}{lccc}
\hline Research & $\begin{array}{c}\text { Placement density } \\
\left(\mathbf{k g ~ m}^{-\mathbf{3}}\right)\end{array}$ & $\begin{array}{c}\text { Total quantity } \\
(\mathbf{k g})\end{array}$ & $\begin{array}{c}\text { Dry matter } \\
(\mathbf{\%})\end{array}$ \\
\hline Stage-1 control landfill & 756.0 & 2727.9 & 35.0 \\
Stage-2 LBR-1 & 527.5 & 1149.6 & 34.5 \\
Stage-2 LBR-2 & 580.0 & 2052.7 & 31.9 \\
Stage-3 LBR 'test cell' & 756.3 & $51,940.0$ & 72.2 \\
\hline
\end{tabular}

Table 2. Different parameters analyzed

\begin{tabular}{|c|c|c|c|c|}
\hline Research & \multicolumn{2}{|c|}{ Leachate parameters } & \multicolumn{2}{|c|}{ Other parameters } \\
\hline Stage-1 lysimeter & \multicolumn{2}{|l|}{ TS, VS } & \multicolumn{2}{|c|}{$\begin{array}{l}\text { Leachate seeping rate, rainfall } \\
\text { waste composition }\end{array}$} \\
\hline Stage-2 LBR-1 & \multicolumn{2}{|c|}{$\mathrm{BOD}, \mathrm{COD}, \mathrm{pH}$} & \multicolumn{2}{|c|}{ Re-circulate amount, waste composition } \\
\hline Stage-2 LBR-2 & \multicolumn{2}{|c|}{$\mathrm{BOD}, \mathrm{COD}$} & \multicolumn{2}{|c|}{$\begin{array}{l}\text { Re-circulate amount, gas volume, waste } \\
\text { composition }\end{array}$} \\
\hline $\begin{array}{l}\text { Stage- } 3 \text { LBR } \\
\text { 'test cell' }\end{array}$ & \multicolumn{2}{|c|}{ BOD, COD, nitrate, } & \multicolumn{2}{|c|}{$\begin{array}{l}\text { settlement, gas extraction rate, } \\
\text { permiability, waste composition }\end{array}$} \\
\hline \multicolumn{5}{|c|}{$\begin{array}{l}\text { Note: TS - Total Solids; VS - Volatile Solids; BOD - Biochemical Oxygen Demand; COD - Chemical Oxygen } \\
\text { Demand; }\end{array}$} \\
\hline $\begin{array}{l}\text { Reactor and } \\
\text { stage }\end{array}$ & Status & $\begin{array}{l}\text { Numbers of days } \\
\text { operate }\end{array}$ & $\begin{array}{l}\text { Frequency of } \\
\text { sampling }\end{array}$ & Remarks \\
\hline $\begin{array}{l}\text { Stage-1 } \\
\text { Control } \\
\text { landfill }\end{array}$ & completed & $\begin{array}{l}16,07,2003 \text { to } \\
15,05,2008 \text { (1772 } \\
\text { days) }\end{array}$ & Once a week & \\
\hline Stage-2 LBR-1 & completed & $\begin{array}{l}21,07,2006 \text { to } \\
14,11,2006 \text { ( } 117 \\
\text { days) }\end{array}$ & daily & $\begin{array}{l}\text { Cow dung added on } \\
66 \text { th day, Lime was } \\
\text { added on 67th day }\end{array}$ \\
\hline Stage-2 LBR-2 & completed & $\begin{array}{l}31,06.2006 \text { to } \\
21,06,2007(172 \\
\text { days) }\end{array}$ & daily & $\begin{array}{l}\text { Water added after } 11 \\
\text { day, and } 21 \text { day }\end{array}$ \\
\hline $\begin{array}{l}\text { Stage-3 LBR } \\
\text { 'test cell' }\end{array}$ & continued & From $26,03,2007$ & $\begin{array}{l}\text { First } 6 \text { month } \\
\text { daily then up to } \\
365 \text { day } \\
\text { weekly, then } \\
\text { monthly }\end{array}$ & $\begin{array}{l}\text { Settlement reference } \\
\text { change after } 268 \\
\text { days due to animal } \\
\text { attack }\end{array}$ \\
\hline
\end{tabular}




\section{RESULTS AND DISCUSSION}

After conducting the above four studies sequentially, the following results were obtained. The composition of MSW in each and every study is given in Table 4.

Table 4. Composition of MSW in each Study

\begin{tabular}{lrrrr}
\hline Composition (\%) & $\begin{array}{r}\text { Stage 1 } \\
\text { lysimeter }\end{array}$ & $\begin{array}{r}\text { Stage 2 } \\
\text { LBR-1 }\end{array}$ & $\begin{array}{r}\text { Stage 2 } \\
\text { LBR-2 }\end{array}$ & $\begin{array}{r}\text { Stage 3 LBR } \\
\text { test cell }\end{array}$ \\
\hline Biodegradable short term & & 44 \\
Garden waste & & - & 59.8 & 60.2 \\
Paper / Cardboard & & 15 & 19.2 & 8.7 \\
Fiber & & 13 & 1.7 & - \\
Wood & & 1 & 0.5 & 0.5 \\
Coconut husk, comb, shell & & 9 & 2.5 & 16.2 \\
Plastic & & 2 & 1 & 1.4 \\
Polyethylene & 12.8 & 11 & 5.1 & 5.8 \\
Metal & 0.2 & 1 & - & 0.7 \\
Glass & 3 & 1 & 1 & 1.3 \\
Textile & - & - & 2.1 & 2.7 \\
Other & 3 & 3 & 4.5 & 2.5 \\
\hline
\end{tabular}

The analyzed data from the composition study for the four studies show that the percentage of organic waste is more than $60 \%$ which is the general trend in the organic fraction of MSW in Sri Lanka (MENR, 2005). The waste compositions are almost similar except coconut husk, comb, and shell percentages. Therefore, input biodegradable raw materials for studies were almost same. It should be noted that, in the test cell the moisture content was very less at the time of laboratory experimentation.

\section{Stage-1 Simulation of controlled landfill conditions}

The stage-1 simulation of controlled landfill research study was conducted over four years. The quantity of leachate generation was affected by many factors such as, precipitation, moisture content and density of waste, evaporation, gas production, and final cover design. However, the precipitation represents the single largest contribution for the generation of leachate (Koerner and Daniel, 1997; Reinhart and Townsend, 1998). Leachate production due to rainfall are shown in Fig. 5. The cumulative values show the sorption properties of the wastes. Cumulative total solids (TS) and volatile solids (VS) shown in Fig. 6 have gradual increments, which show the outcome of the microbial activity in the landfill body and substrate availability in the controlled landfill. 


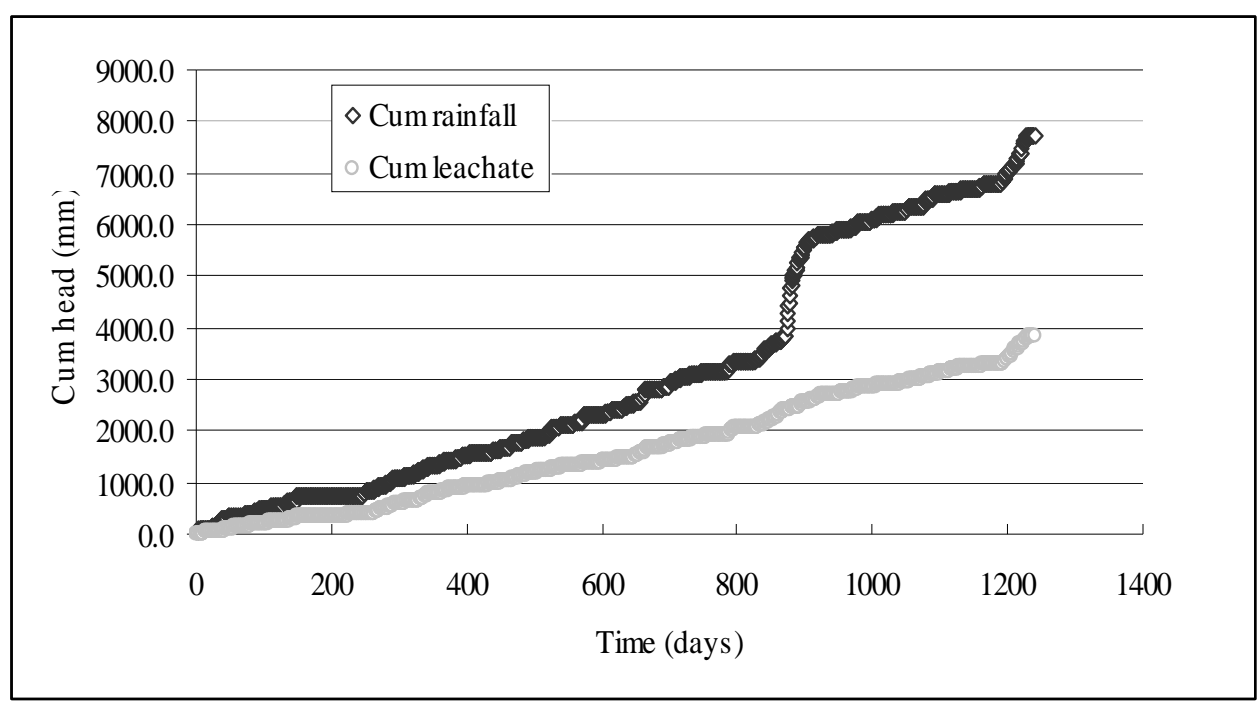

Fig. 5. Cumulative leachate and rainfall variation with time

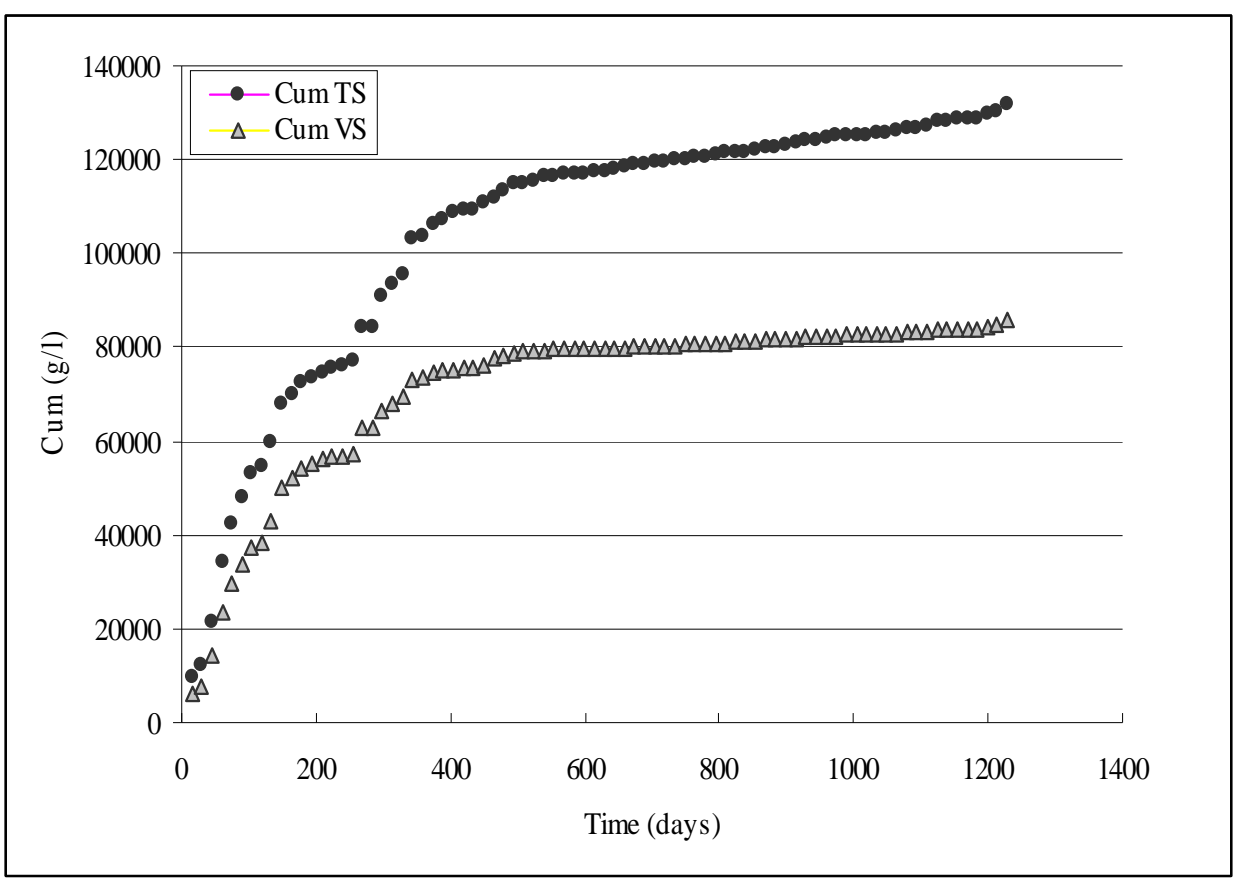

Fig. 6. Cumulative TS and VS production

\section{Stage-2 Simulation of bioreactor landfill conditions in LBR-1}

The Biochemical Oxygen Demand $\left(\mathrm{BOD}_{5}\right)$ remained more or less constant in the stage-2 LBR-1, while significant increment of Chemical Oxygen Demand (COD) occurred as shown 
in Fig. 7, since dung has a high level of inorganic matter. The $\mathrm{pH}$ after 80 days remained in the acidic range as shown in Fig. 8, which indicates the delayed methanogenesis phase.

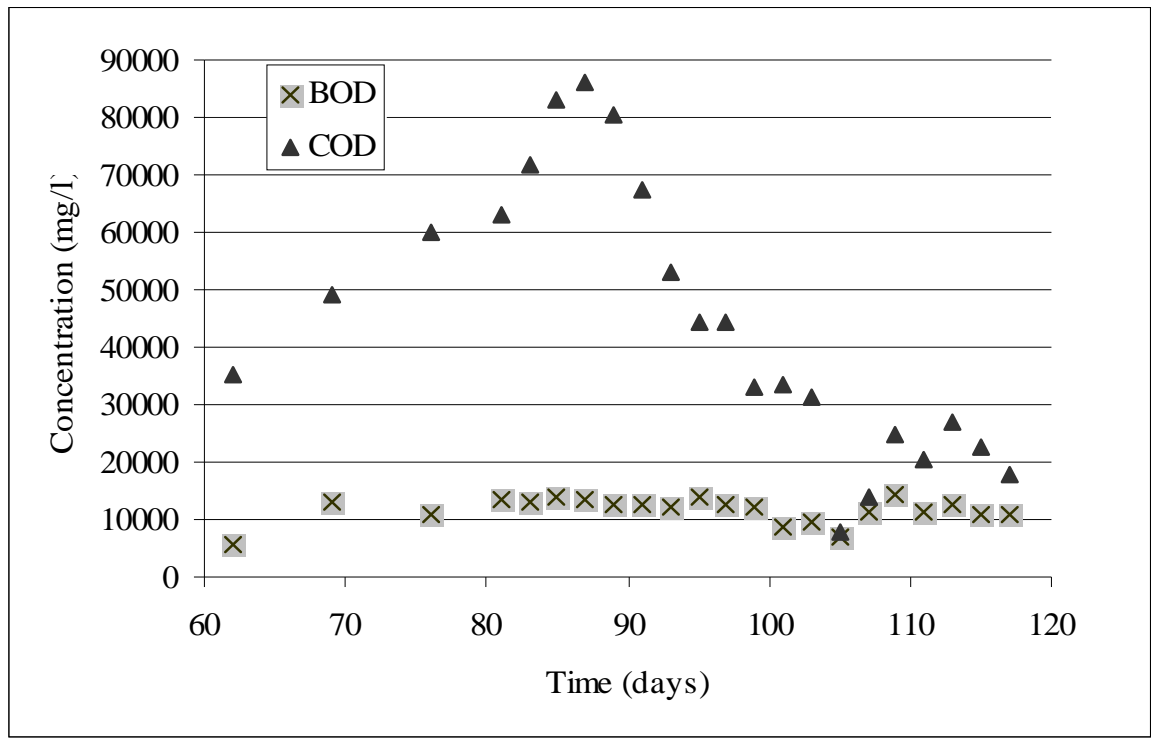

\section{Fig. 7. $\mathrm{BOD}_{5}$ and COD Variations in leachate from LBR-1 at stage2}

Because of lime $\left(\mathrm{CaCO}_{3}\right)$ addition for $\mathrm{pH}$ buffer at 68 and 69 days, the $\mathrm{pH}$ reached to around 8 (Fig. 8). The very high COD concentrations of leachate (peaked at $86,000 \mathrm{mg} \mathrm{L}^{-1}$ ) indicate its high organic and inorganic strengths. After 66 days, there were high biological activities because of cowdung inoculation and it steadily declined to $8,000 \mathrm{mg} \mathrm{L}^{-1}$ after 100 days due to increased leachate recirculation frequency from 3 times per day to 6 .

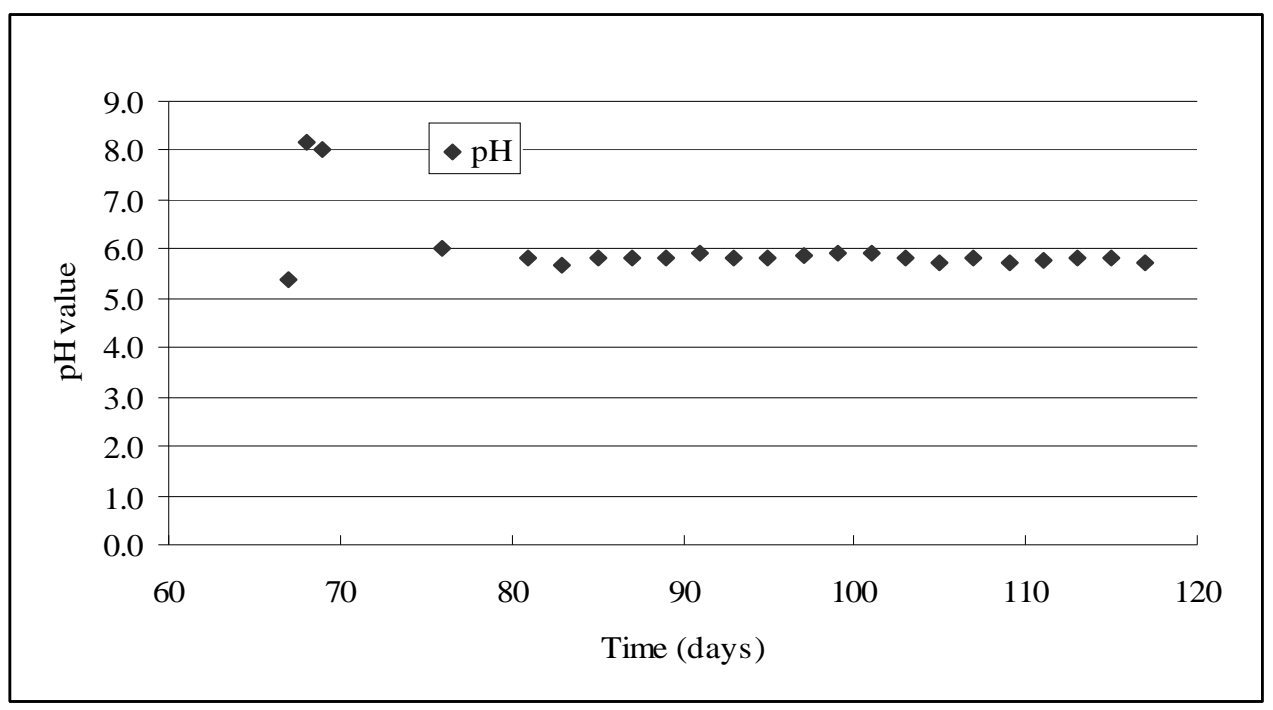

Fig. 8. pH variation in leachate from LBR-1 at stage-2 
After completion of the above stage-2 LBR-1, the LBR-2 was constructed to further evaluate the performance of LBR-1 while isolating the reactor from surrounding environmental conditions such as evaporation and rainfall. Initially gas production increased with the water additions and recirculation, but after 120 days it drastically reduced (Fig. 9). At the same time, $\mathrm{COD}$ and $\mathrm{BOD}_{5}$ levels increased as shown in Fig.e 10. It was convincing to observe that LBR-2 did not follow normal degradation patterns and perhaps created inhibitions. There are many supportive evidences of inhibitions and toxic reported by many authors (Dave and Nilsson, 2005; Poh and Chong, 2008).

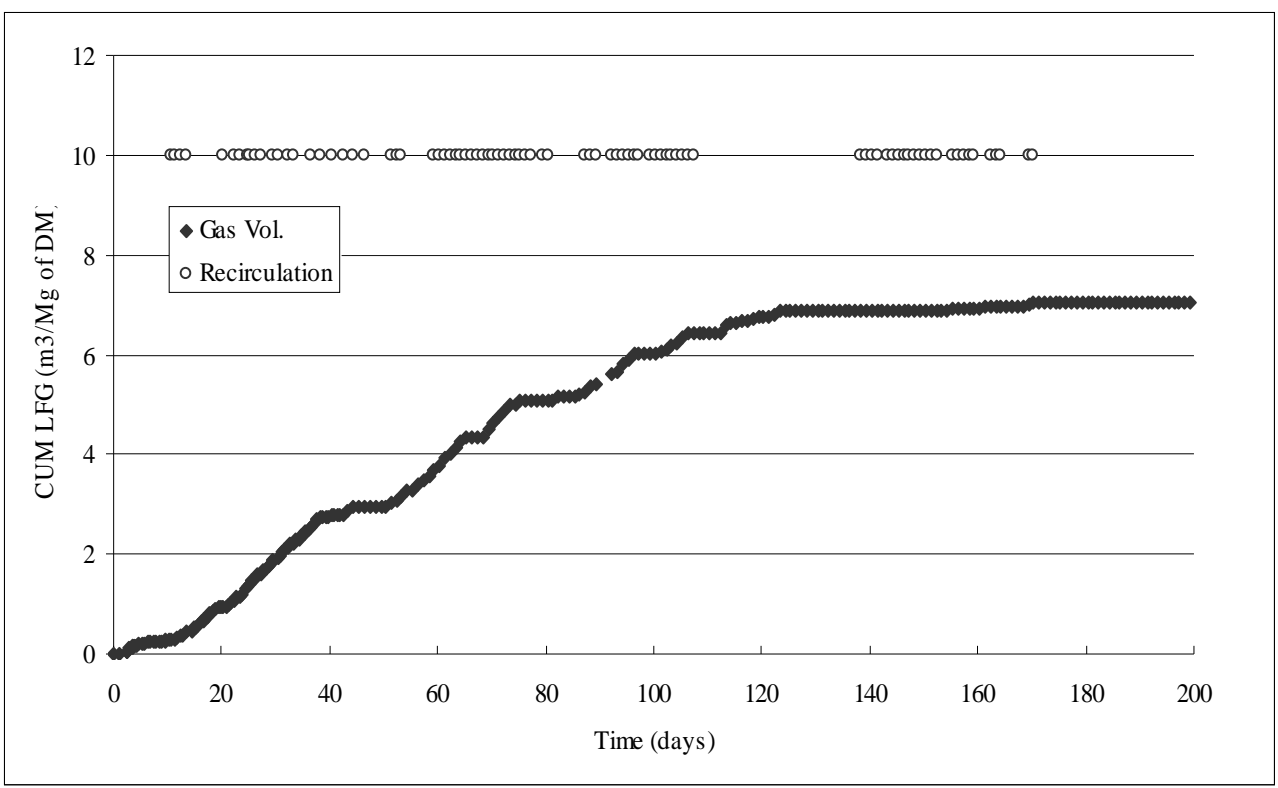

Fig. 9. Gas production and re-circulation variation with time in LBR-2

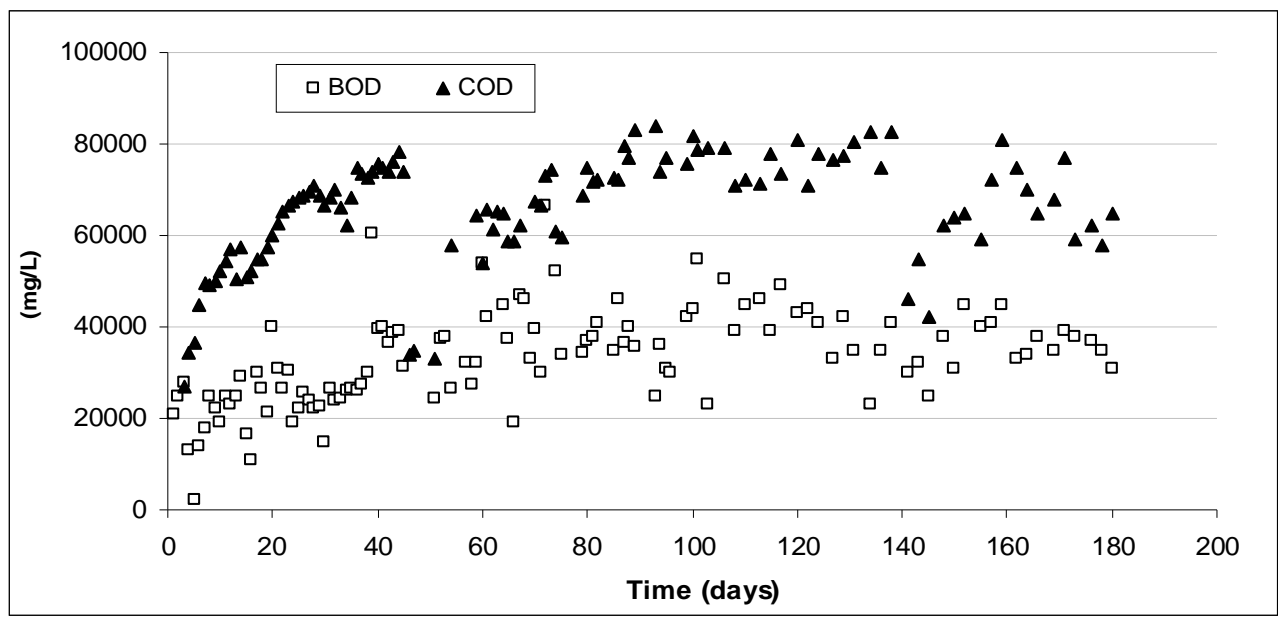

Fig.10. COD and BOD variations with time in $L B R-2$ 


\section{Stage 3 - Simulation of bioreactor landfill 'test cell'}

The stage-3 LBR 'test cell' was invented to overcome the limitations in the above stage-2 studies while maintaining continuous gas production. The forced extraction rate was $4.2 \mathrm{~L}$ per min. of landfill gas and it was torched to minimize the environmental pollution. The new clay-polyethylene-clay liner too eliminated pollution having permeability of $1.0 \times 10^{-7}$ to 1.4 $10^{-7} \mathrm{~cm} \mathrm{sec}^{-1}$ in 35.0 to $97.7 \mathrm{~cm}$ hydraulic range (Gunarathna et al., 2007). Therefore, this liner reached the accepted standard value of $1.0 \times 10^{-7} \mathrm{~cm} \mathrm{~s}^{-1}$ (Qian et al., 2002).

Fig. 11 shows $\mathrm{BOD}_{5}$ and $\mathrm{COD}$ values above the liner, which recorded high values of 30,500 and $73,700 \mathrm{mg} \mathrm{L}^{-1}$, respectively. The $\mathrm{COD}$ and $\mathrm{BOD}_{5}$ drastically reduced from 73,700 to $7,000 \mathrm{mg} \mathrm{L}^{-1}$ respectively within 90 days compared to previous studies (Fig. 11) and settlement for the same is shown in Fig. 12, where there was rapid stabilization of landfill bioreactor 'test cell' under tropical climatic conditions. However, the permeate which is the liquid collected after passing through the liner, even at present, maintains very low average COD values between 4-5 $\mathrm{mg} \mathrm{L}^{-1}$, indicating purification processes (Basnayake et al., 2008).

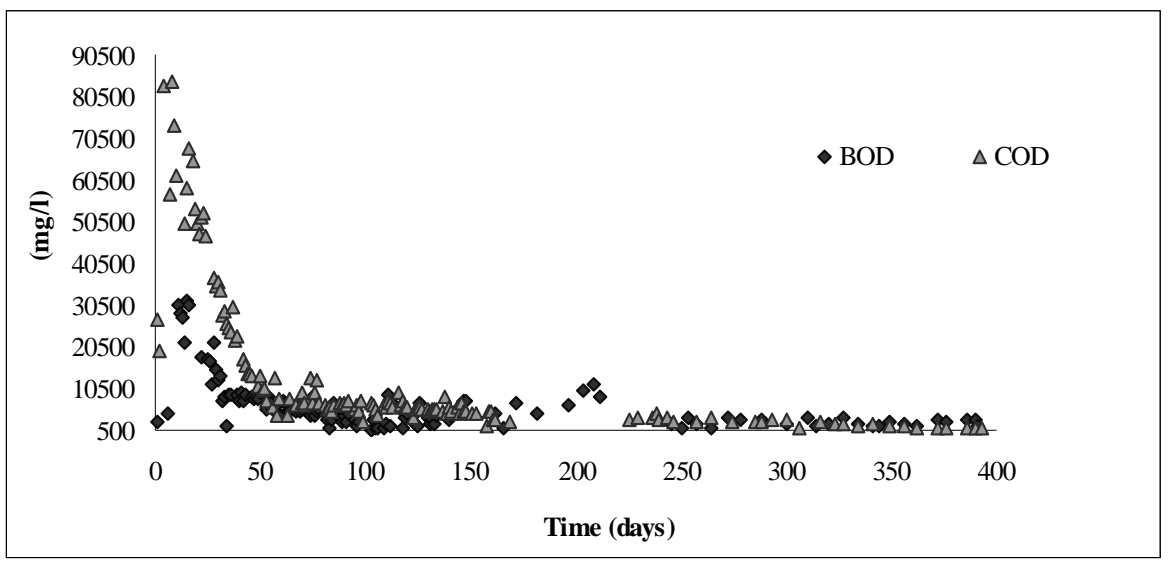

\section{Fig. 11. Variations of BOD and COD with time}

Most of the anaerobic digesters in the world have recorded high $\mathrm{BOD}_{5}$ and COD levels due to ammonia toxicity with time of operation (Dave and Nilsson, 2005). In this LBR 'test cell' composite liner must have provided annamox bacterium processes to take place in the bottom of the landfill to convert ammonia to nitrate (Clabaugh 2001). The liner allowed nitrate nitrogen removal at the rate of $30.1 \pm 1.9 \mathrm{mg} \mathrm{L}^{-1}$. In fact there was an absence of ammonia throughout the experimentation showing only low levels of nitrate. Therefore, it is conclusive that the composite liner promotes annamox process that reduces ammonia toxicity in landfills under anaerobic conditions. 


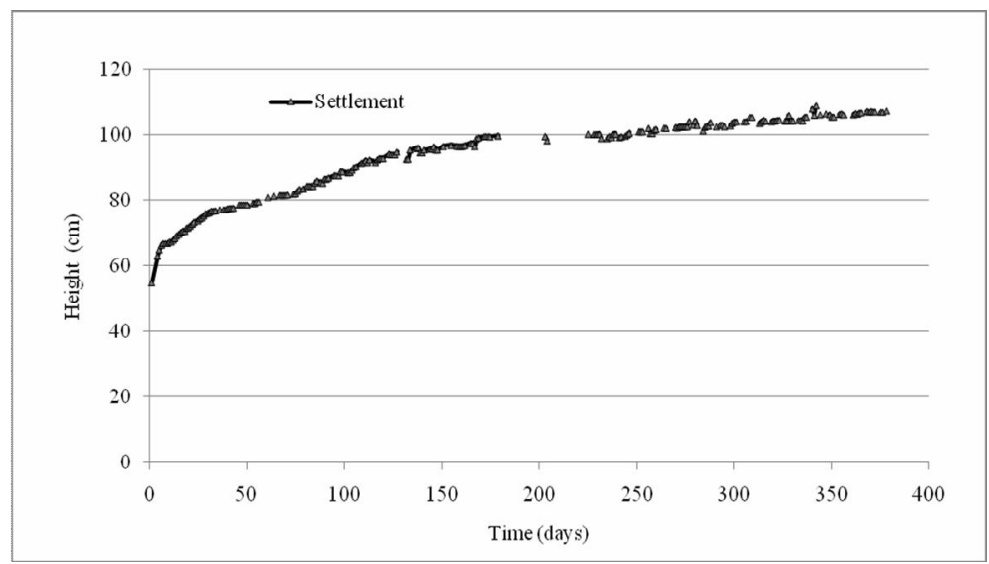

Fig. 12. Variations of settlement of wastes in LBR 'test cell'

The top cover too, certainly has had an effect on gas production. Although, it allowed water to enter the cell, it also prevented gas from escaping since moisture saturation conditions exists in cover in most instances due to frequent addition of moisture from rainfall and irrigation. The gas extraction rate was $4.2 \mathrm{~L}$ per min. for the initial disposal of 52 tonnes of wastes since 2007 . The gas productions began very much earlier ( 3 months after waste filling) than reported (Pohland and Harper, 1986). Perhaps, it is the fastest rate so far for landfill bioreactors/biocells.

\section{CONCLUSIONS}

The development of MSW landfill bioreactors for tropics required simulations with a series of reactors. Stage-1 lysimeter study provided information on landfill leachate generations and biological degradation conditions under tropical precipitation conditions. It necessitated acceleration of biological processes by leachate recirculation and inoculation of cowdung in LBR-1 of the stage-2. Nevertheless under isolated conditions, LBR-2 created inhibitions and toxicity and reduced the gas production performance. Finally, the clay-polyethylene-clay liner of the LBR 'test cell' did overcome drawbacks through removing excess nitrogen and ionic compounds usually prevailing in most systems and achieving standard permeability in MSW landfill liners. This evaluation of the 'test cell' is very useful for designing landfill bioreactors to safeguard the environment for future generation and generating helpful renewable energy for emergent power requirements.

\section{ACKNOWLEDGEMENT}

The Authors are most grateful to the Swedish International Development Agency (SIDA) and Asian Instituted of Technology (AIT) for technical and financial support given for the project; Sustainable Solid Waste Landfill Management in Asia under the Regional Research Programme on Environmental Technologies (ARRPET) 


\section{REFERENCES}

Basnayake, B.F.A., Karunarathne, S.A., Gunarathna, H.A.Y.R. and Murugathasan, S. (2008). Evaluation of reactivity and inhibitions in municipal solid waste dumpsites and landfills in the humid tropical regions in Sri Lanka. In: APPLAS, Sapporo, Hokkaido, Japan, 22-24 October, 2008.

Clabaugh M.M. (2001). Nitrification of landfill leachate by biofilm columns. Msc thesis Faculty of the Virginia Polytechnic Institute and State University, Blacksburg, Virginia.

Das, K.C., Smith, M.C. and Gattie, D.K. (2002). Stability and quality of Municipal Solid Waste compost from landfill aerobic biodegradation process. J. Ad. Envt. Res. 6: 401-409.

Dave, G. and Nilsson, E. (2005). Increase reproductive toxicity of landfill leachate after degradation was caused by nitrate. J. Aqua. Toxico. 73: 11-30.

Gunarathna, H.A.Y.R., Kapukotuwa, A.S.B., Karunarathna, A.K. and Basnayake, B.F.A. (2007). Construction and Evaluation of a Low Cost, Wasted Polyethylene Based Liner for small Landfills. pp. 226-233. International Conference on Solid Waste Management, Chennai, India.

Koerner, R.M. and Daniel, D.E. (1997). Final cover for solid waste landfills and abandoned Dump, ASCE Press. Reston, V.A and Thomas Telford, London, UK.

Loizidou, M. and Kapetanios, E.G. (1993). Effect of leachate from landfills on underground water quality. J. Sci of the Total Env. 128: 69-81.

MENR, (2005). Ministry of environment and natural resources. Database of municipal solid waste in Sri Lanka, Battaramulla, Sri Lanka.

Nagendran, R., Selvam, A., Joseph, K. and Chiemchaisri, C. (2006). Phytoremediation and rehabilitation of municipal solid waste landfills and dumpsites. J. Waste Mgt. 26: 1357-1369.

Poh, P.E. and Chong, M.F. (2009). Development of anaerobic digestion for palm oil mill effluent treatment. . Bioresource Technol. 100: 1-9.

Pohland, F.G. and Harper, S.R. (1986). Critical review and summary of leachate and gas production from landfills. EPA/600/2-86/076 Report, US Environmental Protection Agency, Cincinnati, $\mathrm{OH}$.

Qian, X., Koerner, R. M. and Gray, D.H. (2002). Geotechnical aspects of landfill design and construction. Prentice-Hall, New Jersey, NJ.

Reinhart, D.R. and Tounsend, T.G. (1998). Landfill bioreactor design and operation. Leusis publishers, USA.

Sanphotia, N., Towprayoona, S., Chaiprasert, P. and Nopharatan, A. (2006). The effects of leachate recirculation with supplemental water addition on methane production and waste decomposition in a simulated tropical landfill. J. Envt. Mgt. 81: 27-35.

Sponza, D.T. and Agdag, O.N. (2003). Impact of leachate recirculation and recirculation volume on stabilization of municipal solid wastes in simulated anaerobic bioreactors. J. Process Biochem. 39: 2157-2165. 